\title{
My View on Confucius' Musical Aesthetics
}

\section{Xiong Wen}

Institution Name: Jiangxi Normal University

Address: 99 Ziyang Avenue, Nanchang City, Jiangxi Province

Zip code: 330000

Abstract: During the Spring and Autumn Period and Warring States Period, the ideology environment was severe. Hundreds of scholars competed and argued, and they all used their own musical concepts and aesthetic consciousness to influence social life. Confucius was one of them. As we all know, Confucius was the great pre-Qin period thinker, politician, and educator of etiquette and music. His achievements in music aesthetics are different from other schools of "contend of a hundred schools of thought". Confucius's aesthetic thoughts are actually the aesthetic thoughts he formed in the practice of ritual and music education. This article discusses his musical spirit, the aesthetic propositions of "benevolence", "perfect perfection", "neutrality", and music education.

Keywords: Confucius; benevolence; goodness and beauty; neutralization

\section{The core content of Confucius' music aesthetics-"benevolence"}

During the Spring and Autumn Period and Warring States Period, the Zhou royal family declined, the feudal princes rose, and rituals collapsed. In this period, the value and influence of the ritual and music culture of the Zhou Dynasty on the world at that time has faded. Therefore, "benevolence" as a moral emotion and a spirit of fraternity at this time was proposed by Confucius. The author believes that this "benevolence" is not an ornament subject to "rituals", but the core content of rituals and music.

The author believes that in Confucius' music education thought, "benevolence" adds the spiritual content of fraternity to "le", which makes the emotion of "le" attached to the soul, becoming more grand and fulfilling. "Benevolence", for the implementation of "rituals", puts forward the requirements of dealing with people and standard of behavior, so that "people" will not be alienated and separated due to differences in ranks. Xiu Hailin mentioned in "The Aesthetics of Ancient Chinese Music" that in the aesthetics of the pre-Qin period, Confucius mentioned that "people who are not benevolent have no courtesy, and people who are not benevolent cannot appreciate music." The author believes that he is emphasizing that the prerequisite for people to be taught rituals and music is they have benevolence, because "benevolence" is an inner spirit. If there is no "benevolence" thinking, it will only be a gorgeous shell that has no content inside. The author believes that the realm of music lies in people's moral sentiment, the higher the sentiment, the higher their ability to comprehend the realm of music. The reason why Confucius advocated the mutual connection of the beauty of human morality and the beauty of music is to take "benevolence" as the core and standard of aesthetic appreciation of music. That is, "benevolence" is not an ornament subject to "li", but the core content of ritual music.

\section{Put forward the aesthetic evaluation standard of "perfect and perfect"}

According to the information obtained by the author, in the history of Chinese music aesthetics, Confucius first clearly used the concept words "beauty" and "good" to distinguish the beauty of content from the beauty of form. He

Copyright () 2020 Xiong Wen

doi: $10.18282 /$ le.v9i7.1473

This is an open-access article distributed under the terms of the Creative Commons Attribution Non-Commercial License

(http://creativecommons.org/licenses/by-nc/4.0/), which permits unrestricted non-commercial use, distribution, and reproduction in any medium, provided the original work is properly cited. 
proposed that the two can be unified in contradiction. "The Analects of Confucius and the Eight Immortals" recorded that "Zi said that "Shao" is perfect and beautiful, and that "Wu" is beautiful but not perfect." [1] The author believes that Confucius makes a clear theoretical distinction between "beauty", the political and moral standard of music and dance and the art form standard "goodness". Under the premise of affirming the value of "beauty" (formal beauty), "goodness" is proposed as the primary aesthetic standard for evaluating music and art works. Obviously, this does not indicate what he pursues is the harmonious unity of "beauty" and "goodness" under the premise of "goodness" as the leading factor, that is, the unity of contradictions.

\section{The aesthetic principle of "neutrality" of "happiness but not lust, sorrow but not hurt"}

The book "The Aesthetics of Ancient Chinese Music" mentioned that the "Analects of Confucius" recorded Confucius's evaluative opinions based on his own aesthetic propositions when he was appreciating the poetry and music work "Guanju". From the perspective of the notion of "happiness but not lust, sorrow but not hurt", he advocated the expression of emotion as "appropriate expression of emotion", "restricted expression of emotion" and "moderate expression of emotion". The author believes that Confucius's concept is actually to make sure that the internal emotional experience and external performance of music aesthetics be kept correct, and be in a proper and harmonious state. "happiness" and "sorrow" are both concrete expressions of human life emotions. In the expression, artistic emotions are processed unlike the specific expression of life emotions, in expression, artistic emotions will be processed differently from life emotions. Art creation should be more or less reserved, otherwise it will lead to "water overflows", the author believes that Confucius's aesthetics can fully demonstrate his requirement of "neutralization" through the evaluation of " happiness but not lust, sorrow but not hurt ", because he believes that unbeautiful music will violate "neutralization." The principle of "the golden mean" is that only by "neutralizing" the artistic emotions in music can the works be exhibited in the best emotional dimension, so that people can truly feel the beauty of music and works when they appreciate the works.

The author believes that Confucius classifies all behaviors that are too detrimental to emotions or that do not achieve emotions as not the ultimate goal of aesthetics, because it is mentioned in the book "Ancient Chinese Music" that Confucius advocates " happiness but not lust, sorrow but not hurt ". Yayue is a folk music that criticizes the "Voice of Zheng Wei". He believes that the "Voice of Zheng Wei" is "Zheng Wei's obscene" and "playing the voice of Zheng", that is, he has strong indignation at the "Voice of Zheng Wei" because "The Voice of Zheng Wei" is a city entertainment music in a modernized environment, which is more radical, enthusiastic, and has a spirit of resistance, which will have a certain degree of adverse impact on cultivating sentiment and social education. The author believes that from the point of view of Confucius's musical ideology, which promotes elegant music and suppresses vulgarity, Confucius's ideology more or less contains some prejudices held by traditional feudal classes, but from his "neutral" music from an aesthetic point of view. The author believes that his proposition has had a profound impact on music creation and music appreciation in later generations.

\section{The cultivation of aesthetic emotions in the thought of music education and its role in aesthetic education}

\subsection{Deepen the rich emotional experience in the grasp of the beauty of music}

As its name implies, "Yue Jiao" is music education. The author believes that Confucius's music education is not only the training of vocal singing or instrumental performance, but also the understanding, appreciation and acceptance of music, "The Analects of Confucius" "Taibo" records that Confucius once said, "The beginning of Shi Zhi, the chaos of Guanju, is exuberant and full of ears!" ${ }^{\mathbf{I} 2 \mathbf{I}}$ In the vernacular, it means that musician Zhi played music. In the process, Confucius listened conscientiously. Seriously, even a little bit mesmerized, and after listening to it, he still uttered a compliment of "blooming, full of ears". Confucius inspires students by explaining music to students, introducing his own understanding of music, and his own aesthetic, aesthetic, and emotional experience. This is to help students under- 
stand the beauty of the music form and deepen the students' appreciation of the musicians' music. Emotional experience.

\subsection{Emphasize the difference between aesthetic experience and pleasure experience in music aesthetics}

The students of Confucius once wrote down the feelings Confucius made after listening to "Shao": "The Master is listening to "Shao", and he doesn't know the smell of meat for three months, and said: "I didn't expect the charm of music can be so astounding!" The meaning of the sentence is that Confucius once heard the music of "Shao" when he was in Qi State, was deeply moved by it, and was intoxicated by it. Since then, he has forgotten the taste of meat for three months. ${ }^{\mathbf{I} \mathbf{I}}$ The author believes that when Confucius tells his students how he feels, he is not merely expressing the meaning of "not knowing the taste of meat" for many days, but at a deeper level, he wants to express that he is so immersed in this kind of music. It can be seen from this that the author believes that Confucius is a tasteful music connoisseur, and his experience of music shows the effect of music on the psychological state. This effect is nuanced and directly enters the depths of the mind. When he talked about his own feelings to students, he did not just express the meaning of "not knowing the taste of meat" for many days. The real meaning is to distinguish the different nature of the aesthetic experience obtained when appreciating music and dance and the pleasure experience of taste. When everyone conflated these things together, Confucius made a clear distinction. This is a memorable milestone in the history of the development of aesthetics and aesthetic education in my country.

\subsection{The state of happiness in Confucius's aesthetics}

"The Analects of Confucius: Advanced" recorded that Confucius asked his disciples to speak, and only approved Zendian's idea of: Those who are late in spring, the spring clothes are completed, there are five or six winners, six or seven boys, want to Yi, dance to the wind, singing and returning. The author believes that it is because Zeng Dian's views have been recognized by Confucius. In a sense, it shows that the state of "joy" praised by Confucius has exceeded Confucius' own limitations. It has surpassed Confucius's desire to achieve a joyful and contented aesthetic in life, and also brought his thoughts into the students he taught, and then has had a great impact on the period he lived in for a long time to this day, and even today.

Conclusion: The author believes that for Confucius, the highest state of life is based on the aesthetic mechanism. To reach this state, you need to know how to appreciate music, so that the value of music can be realized. Knowing how to appreciate music and the value of music means being able to cultivate talents, governing the country, and even achieving world peace, his aesthetics has affected the development of our country's aesthetics for a long time. The author believes that, as music researchers, we must first cultivate our self-awareness and aesthetic abilities. Only by mastering how to appreciate and how to apprise music can we understand and master the true and deeper connotations of music!

\section{References}

1. Xiu Hailin's “Ancient Chinese Music Aesthetics” Chapter 6, The Aesthetic Consciousness of the Scholars in the PreQin Period, Fujian Education Press, the first edition in December 2014.

2. Cai Zhongde, "The History of Chinese Music Aesthetics", Pre-Qin Part, The Analects, p.69, p.70, People's Music Publishing House, 2nd edition in March 2004.

3. Wang Hongjian, "Introduction to Art", Chapter 4, Art Creation Theory, About Artist's Aesthetic Creativity, Page 216-220, Culture and Art Publishing House, October 2010, first edition. 